\title{
KULTUR POLITIK TRADISIONAL JAWA PADA MASA REZIM ORDE BARU TAHUN 1967-1998
}

\author{
Aloysius Kasman ${ }^{1}$ \\ Septa Rahadian² \\ IKIP Budi Utomo Malang \\ loislurut2793@gmail.com
}

\begin{abstract}
ABSTRAK
Penelitian ini bertujuan mendeskripsikan Rezim Orde Baru yang merupakan apa yang dilakukan Orde Baru melalui kekuasannya. Dalam ilmu politik, kekuasaan digunakan untuk mencapai tujuan yang lebih besar, yakni mcenyejahterakan rakyatnya, termasuk ideologi apa yang digunakan. Orde Baru hadir sebagai antitesis dari era demokrasi parlementer dan demokrasi terpimpin membuat, jarak terhadapnya, bahkan memperlihatkan permusuhan terhadap Orde Lama. Kekuasaan Orde Baru bermula pada tahun 1967-1998.

Penelitian ini menggunakan metode sejarah yang merupakan catatan relevansi dengan pemerintahan rezim Orde Baru yang berlandaskan pada kultur politik tradisional Jawa, jauh sebelum kedatangan kolonial Belanda di Nusantara. Metode-metode sejarah yang dipaparkan seperti, Pemilihan Topik (kedekatan emosional dan kedekatan intelektual), Heuristik ( mencari dan mengumpulkan data ), Verifikasi ( kritik sumber buku interen dan eksteren ), Interpretasi (penafsiran) dan Historiografi (catatan sejarah ). Kemudian hasil dari penelitian Kultur politik tradional Jawa yang lahir jauh sebelum masa kolonial Belanda abad ke- xix sebagai dasar efektivitas penyalahgunaan kekuasaan Rezim Orde tahun 1967 sampai 1998 di Indoesia.
\end{abstract}

Kata Kunci: Orde Baru, Kultur Politik Tradisional Jawa

\section{PENDAHULUAN}

Rezim Orde Baru merupakan apa kekuasaan digunakan untuk mencapai yang dilakukan Orde Baru melalui tujuan yang lebih besar, yakni kekuasannya tersebut. Dalam ilmu politik, menyejahterakan rakyatnya, termasuk 
ideologi apa yang digunakan. Pada masa

Orde Lama, Soekarno melalui pengalamannya dalam aktivitas dunia politik dan pergulatanpemikirannya, menelurkan suatu konsep, nasionalisme, Islam, dan komunis atau yang disebut Nasakom. Melalui hal itu, kebijakankebijakan politik diarahkan untuk mencapai ide tersebut. Soekarno konsisten dengan pemikirannya. Oleh karena itu, pada titik ini kekuasaan dipergunakan sebagai alat untuk mencapai suatu tujuan besar, yakni terwujudnya Nasakom. Soekarno dengan kekuasaannya bertujuan untuk mencapai Nasakom dengan cara yang semakin terpusat. Namun, pertentangan antara golongan komunis dan pendukung Soeharto berhadapan dengan TNI AD dan kelompok nonkomunis tidak bisa diatasi Soekarno (Rizkiandi, 2016: 7).

Arogansi ini ternyata meluas sampai ke kalangan bawahan juga, sehingga akhirnya $A B R I$ seolah-olah merupakan golongan tersendiri dengan hak-hak tersendiri melebihi hak-hak warga negara lainya. Warga $A B R I$ merasa dirinya sebagai warga negara kelas satu. Normanorma hukum dan peraturan yang berlaku bagi masyarakat sipil, tidak berlaku atau tidak dapat diberlakukan terhadap warga ABRI (Soemardjan, 1999: 123).
$A B R I$ selalu mendapat perlakuan lain dari pada masyarakat biasa, selalu mendapat perlakuan istimewa. ABRI menjadi berkepentingan mempertahankan keadaan yang demikian itu, mempertahankan rezim Orde Baru atau Rezim Soeharto. Dengan kata lain, ABRI dan Golkar berkepentingan mempertahankan status quo dan dengan demikian ia mereduksikan dirinya alat pelaksana belaka dari presiden atau Panglima Tertinggi Soeharto. Angkatan Bersenjata Republik Indonesia ( ABRI) sebagai kekuatan sosial dan politik tidak lagi merupakan mitra dari kekuatankekuatan sosial dan politik lainya, mitra tanpa berpihak kepada salah satu dari padanya sesuai Doktrin Perjuangan TNIABRI "Catur Dharma Eka Karma” ( CADEK ) tahun 1988 yang menyebutkan bahwa "sebagai kekuatan sosial politik ABRI merupakan teman seperjuangan yang sejajar dan sederajat dengan kekuatan sosial lainnya yang berpedoman Pancasila sebagai satu-satunya asas" (pasal 38 ayat a) (Soemardjan, 1999: 123).

Ulasan sangat menarik terdapat tentang hal itu terdapat dalam tulisan Benedict Anderson pada 1977, "The idea of power in Javanese culture". Gambaran tentang tata pemerintahan Jawa sebagaimana disebutkan Anderson dalam 
tulisannya, "merupakan kerucut cahaya yang memancar ke bawah lewat lampu reflektor". Pemikiran Tradisional Jawa secara impisit mengabaikan pendekatan hirarki, "karena hirarki mengandung arti suatu derajat otonomi pada berbagai tindakan," Sedangkan secara ideal yang diperlukan ialah suatu sumber kekuatan dan otoritas tunggal yang mudah tersebar. Inti pemerintahan tradisional ialah sang penguasa yang mencerminkan personifikasi kesatuan masyarakat (Jenkins, 2010: 19).

Muncul kembali bentuk-bentuk pemerintahan sebelum masa kolonial Belanda sering mendapat komentar dan dikutuk oleh orang Indonesia. Bahkan tidak sedikit para petinggi militer terkemuka berharap Orde Baru akan memenuhi janjinya pada 1966 untuk melakukan "koreksi total" setelah adanya berbagai ekses di masa silam. Banyak kritikus mencela cara cara-cara Soeharto memerintah seperti "Mataram baru," suatu sindiran mengacu kerajaan penting di Jawa setelah 1582 dan pada keberhasilan presiden dalam membangun suasana kraton Jawa. Ini mengacu situasi dimana politik sering menjadi intrik di balik layar dengan seorang "pangeran" yang kuat mempecundangi yang lain dengan adu domaba menjunjung tinggi sang penguasa. Menurut para pengkritik, orang tidak perlu melihat jauh untuk menemukan penguasa yang mengikuti bentuk-bentuk tradisional dengan menggunakan kekuasaannya guna memberikan alokasi tertentu kepada bawahan (Jenkins, 2010: 20-21).

\section{METODE PENELITIAN}

\section{A. Pemilihan Topik}

1. Kedekatan Emosional

Dalam artikel ini, peneliti memilih topik kajian yang berjudul "Kultur Politik Tradisional Jawa Pada Masa Rezim Orde Baru Tahun 1967-1998". Alasan peneliti memilih topik ini karena peneliti sangat tertarik dan senang untuk mengulasnya kembali meskipun peristiwa sudah berlalu serta besar faedahnya bagi kehidupan yang sekarang dan yang akan datang.

2. Kedekatan Intelektual Untuk mencapai kesempurnaan dan kejelasan terkait topik yang yang disajikan, dengan judul "Kultur Politik Tradisional Jawa Pada Masa Rezim Orde Baru Tahun 1967-1998". Sebagai penunjang karya tulisan, peneliti sudah mengumpul berbagai sumber evidensi (bukti) berupa buku-buku sebagai rujukan. Dari setiap sumber buku peneliti dapat menilai secara tersendiri masing-masing isi buku terkait dengan judul penelitian. Ada pun dari 
beberapa sumber buku untuk menunjang penelitian ini, bahkan di bangku perkuliahan juga sedikit peneliti temukan terkait dengan judul penelitian kekuasan rezim Orde Baru tersebut.

\section{B. Pengumpulan Sumber (Heuristik)}

Pada artikel ini, peneliti menggunakan sumber Skunder (studi pustaka), yakni menggunakan sumber buku-buku sebagai penopang dalam penelitian yang berjudul "Kultur Politik Tradisional Jawa Pada Masa Rezim Orde Baru Tahun 1967-1998". Kemudian sumber buku-buku sebagai penunjang karya tulisan ini, disajikan dan dibahas, yakni: "Kisah Yang Tak Terungkap: Mahasiswa dalam Pusaran Reformasi 1998, penulis Rosidi Rizkiandi. Peneliti memperoleh buku tersebut dari pinjaman teman. Buku ini dipinjam pada 17 Februari 2018; Buku Kisah Perjuangan Reformasi, penulis Selo Soemardjan. Buku ini diperoleh dari pijaman teman. Peneliti meminjam bukunya pada 17 Februari 2018; Politik Indonesia: Transisi Menuju Demokasi, penulis Afan Gaffar. Buku tersebut diperoleh dari perpustakan umum Kota Malang.

Peneliti meminjam buku dari perpustakaan Kota Malang pada 17 Juli 2018; Buku Soeharto Dan Barisan Jendral
Orba Rezim Militer Indonesia 1973-1983, penulis David Jekinds. Buku tersebut diperoleh dari perpustakan umum Kota Malang. Peneliti meminjam buku dari perpustakaan Kota Malang pada 20 februari 2018; Buku Menyilang Jalan Kekuasaan Militer Otoriter: Gerakan Kritis Mahasiswa Militer Otoriter di panggung Politik Indonesia, penulis Rum Aly. 2004. Buku ini didapatkan dari pinjaman buku di Perpustakan Umum Mota Malang. Buku tersebut dipinjam pada 20 Februari 2018; Buku Sosiologi Suatu Pengantar, penulis Soerjono Soekanto. Buku ini adalah milik peneliti sendiri, yang dibeli di wilis pada 20 November 2014; Buku Penganntar IImu Antropologi, penulis Koentjaraningrat 2009. Buku tersebut milik peneliti, yang dibeli di toko buku Wilis pada 20 November 2014; Buku Kehidupan Politik dan Perubahan Sosial, penulis Charles F. Andrain. Buku tersebut peneliti peroleh dari Perpustakan Umum Kota Malang. Buku dipinjam pada 24 Maret 2018; Buku Presidesialisme Setengah Hati: Dari dilemma Ke Kompromi, oleh Hanta Yuda AR. Buku tersebut kemudian diperoleh peneliti dari Perpustakaan Umum Kota Malang. Buku itu dipijam pada 24 Maret 2018; Buku Konsep Kepemimpinan Jawa Dalam Ajaran Sastra Cetha dan Astha Brata, oleh Suyami. 2008. Buku ini 
dipinjam di Perpustakaan Umum Kota Malang. Buku tersebut peneliti pijam pada tanggal 15 Mei 2018; Buku Mutiara Manusia Jawa: Menggali Butiran-Butiran Ajaran Lokal Jawa Untuk Menuju Kearifan hidup Dunia Dan Akhirat, oleh Muhammad Zairul Haq. 2011. Buku itu penulis peroleh dari perpustakaan Umum Kota Malang. Bukunya dipijam pada tanggal 15 mei 2018; Buku Titik Tolak Reformasi: HariHari Terakhir Presiden Soeharto, oleh Edward Aspinall, Dkk. 2000. Buku tersebut miliki penulis sendiri yang dibeli pada 13 April 2017, di Toko buku Wilis; Buku Mahasiswa Menggugat: Potret Gerakan Mahasiswa Indonesia 1998, penulis Fahrus Zaman Fadhly.1999. Buku tersebut penulis atau peneliti peroleh dari pijaman teman, pada tanggal 17 Maret 2018".

\section{Kritik Sumber (Verifikasi)}

1. Kritik Interen

Isi dan tulisan dalam buku tersebut sangat menarik untuk dibaca dan mudah dipahami. Buku-buku tersebut sangat bermanfaat bagi peneliti untuk melakukan penelitian, karena selain untuk menambah wawasan bagi peneliti juga untuk mendapatkan data yang akurat dalammenyempurnahkan tulisan artikel peneliti.

2. Kritik Ekstern
Dalam kritik eksteren ini, peneliti menemukan berbagai pandangan yang berbeda dari beberapa isi sumber buku antara lain misalnya, menurut buku Kisah Yang Tak Terungkap:Mahasiswa dalam Pusaran Reformasi 1998, penulis Rosidi Rizkiandi. Buku ini sangat akurat untuk menunjang tulisan yang berjudul "Kultur Politik Tradisional Jawa Pada Masa Rezim Orde Baru Tahun 1967-1998", Buku Kisah Perjuangan Reformasi, penulis Selo Soemardjan. Buku Soeharto dan Barisan Jendral Orba Rezim Militer Indonesia 1973-1983, penulis David Jekinds. Buku tersebut sangat autentik keabsahannya, yang meskipun pandangan dengan buku lain berbeda, namun tujuan sama. Buku Menyilang Jalan Kekuasaan Militer Otoriter: Gerakan Kritis Mahasiswa Militer Otoriter di panggung Politik Indonesia, penulis Rum Aly. Buku ini lebih akurat, karena isinya detail berkaitan sistem Pemerintahan rezim Orde Baru. Buku Sosiologi Suatu Pengantar, penulis Soerjono Soekanto, Buku Pengantar IImu Antropologi, penulis Koentjaraningrat, 2009. Buku tersebut jaga baik dan cocok, sebab bisa memberikan informasi kepada penulis untuk dijadikan rujukan. Buku Kehidupan Politik dan Perubahan Sosial, penulis Charles F. Andrain, Buku Presidesialisme Setengah Hati: Dari 
dilemma Ke Kompromi, oleh Hanta Yuda

AR. Buku ini ada kaitannya dengan judul penelitian, sehingga dikategori sebagai rujukan. Buku Konsep Kepemimpinan Jawa Dalam Ajaran Sastra Cetha dan Astha Brata, oleh Suyami. Buku Mutiara Manusia Jawa: Menggali Butiran-Butiran Ajaran Lokal Jawa Untuk Menuju Kearifan hidup Dunia Dan Akhirat, oleh Muhammad Zairul Haq. Buku Titik Tolak Reformasi: Hari-Hari Terakhir Presiden Soeharto, oleh Edward Aspinall, Dkk. Buku Mahasiswa Menggugat: Potret Gerakan Mahasiswa Indonesia 1998, penulis Fahrus Zaman Fadhly. Dan buku. Teror Orde Baru: Penyelengan Hukum dan Propogand 1965-1981, oleh Southwood dan Flanangan.

\section{Interprestasi (Penafsiran)}

Penelitian tentang "Kultur politik Tradisional Jawa Pada Masa Rezim Orde Baru Tahun 1967-1998" dapat ditafsirkan bahwa, bangsa Indonesia pada Saat era Orde Baru atau Masa pemerintahan dan kekuasan Soeharto. Rezim Orde Baru berawal dari 1967 sampai 1998 setelah bangsa Indonesia mengalami peristiwa mengerikan, yaitu peristiwa Gerakan 30 September 1965 (G 30S/PKI). Orde Baru adalah sebutan bagi masa pemerintahan Presiden Soeharto di Indonesia. Presiden
Soeharto adalah presiden Indonesia yang ke dua dan menjabat pada periode 1967 sampai 1998.

Soeharto merupakan pimpinan yang cerdik dalam memanfaatkan potensi sosal, politik, budaya dan sejarah bangsa Indonesia. Soeharto menciptakan fobia terhadap politik, kekuasaan, kelompok ideologi dan partai politik di tengah masyarakat. Golongan karya (Golkar) adalah pihak yang diuntungkan karena diidentikan bukan partai politik, berbeda dengan PPP dan PDI. Pada tahun 1970, menjelang pemilu 1971, Orde Baru melakukan kampanye "politik no, pembangunan yes" secara gencar. Orde Baru menafsirkan bahwa partai plitik denan ideologinya masing-masing serta berorientasi kekuasaan merupakan suatu masa lalu yang buruk. Peristiwa konflik ideologis yang berkepanjangan, jatuh bangunnya kabinet pemberontakan DI/TII, dan pemberontakan G 30S/PKI menjadi catatan yang perlu dihindari. Konflik politik tersebut menurun ke masyarakat sehingga terjadi fragmentasi sosial yang memudah memanas dan memicu konflik sosial.

\section{E. Historiografi}

Dimulai pada akhir tahun 1960-an, format politik yang baru dirancang untuk mencapai tujuan-tujuannya. Gambaran 
pokoknya adalah adanya peranan militer yang begitu kuat di dalam politik, birokratisasi dan korporatisasi seluruh organisasi sosial dan organisasi politik, dan cara-cara represif terhadap para oposisi yang dilakukan secara selektif tetapi seringkali dijalankan secara brutal. Orde Baru masih menunjukan ciri-ciri yang sama seperti 1960-an. Muncul dari kekacauan komunal dan konflik politik yang sengit pada dekade itu, yakni pertarungan antara komunisme dengan musuh-musuhnya, kolapsnya ekonomi, dan disintegrasi sosial rezim yang barulahir itu mengutamakan perbaikan terhadap tatanan politik, memprioritaskan pembangunan ekonomi dan melarang patrisipasi massa terhadap politik.

\section{PEMBAHASAN}

\section{A. Penyelewengan Politik}

\section{Kekuasaan Rezim Orde Baru}

Awal masa kepemimpinan, Orde Baru melakukan penataan kehidupan nasional, terutama kelembagaan politik. Orde Baru memandang praktik kelembagaan politik Orde Lama banyak menyeleweng dari Pancasila dan UUD 1945. DPR hasil pemilu 1955 dibubarkan karena tidak menyetujui RAPBN yang diajukan pemerintah. Seluruh anggota DPR baru dibentuk dan diangkat oleh presiden Soekarno. Seluruh anggota MPR yang diangkat oleh presiden menetapkan Soekarno sebagai presiden seumur hidup. Ketua Dewan Pertimbanan Agung dirankap oleh presiden Soekarno dan ketua Mahkamah Agung merangkap menteri Negara. Kelembagaan politik dibenahi sesuai UUD 1945. Seluruh Ketetapan MPR (Tap MPR) ditinjau ulang dan mekanisme kelembagaan negara diatur kembali. Pemilu kembali digelar untuk memilih anggota DPR/MPR baru, tetapi baru terealisasi tahun 1967 (Rizkiandi, 2016: 14).

Sistem politik yang diterapkan Soeharto adalah Sentralistik. Semua perangkat berada di bawah kendali Soeharto. ABRI/TNI, birokrasi dan Golkar sebagai tiang-tiang penopang kekuasaannya adalah perangkat utama yang dikendalikannya. Melalui perankat inilah pergerakan untuk mengendalikan Negara dijalankan. Langkah tersebut dimulai pada tahun 1965 hingga 1970. Masa ini disebut sebagai masa konsolidasi. Tahun 1970 dipilih sebagai akhir dari masa konsolidasi karena karena pada tahun 1971 terjadi pemilu yang menjadi ajang pertarungan pengaruh. Tahun 1967, Soeharto meminta kepada MPR untuk memundurkan pelaksanaan pemilu yang seharusnya dilaksanakan 
1968. Alhasil, pemilu terlaksana pada 1971. Alasan Soeharto adalah menjaga stabilitas politik dan keamanan serta memangun perekonomian yang cukup genting untuk masyarakat saat itu. Hal ini tentu saja hanyalah bentuk alasan Soeharto. Tujuan Soeharto sebenarnya adalah memperkuat posisi dalam pemilu 1971 dan menjadikan dirinya presiden RI secara sah dalam pemilu (Rizkiandi, 2016: 11-12).

Posisi soeharto sebagai Presiden sekaligus sebagai Panglima Tertinggi tidak serta merta dapat mengendalikan ABRI dengan mudah. Dalam tubuh ABRI terdapat kubu yang tidak semuanya mendukung kebijakan-kebijakan Soeharto. Dinamika yang terjadi dalam tubuh ABRI tidak semuanya dapat dikendalikan oleh Soeharto. Maka, penting bagi Soeharto untuk dapat mendapatkan orang-orang pada posisi-posisi strategis atau mempengaruhi pimpinan-pimpinan $A B R I$ yang menduduki posisi strategis. Kedudukan $A B R I$ sangat penting karena menjadi motor penggerak Orde Baru. Tantangan terbesar bagi Soeharto teradi pada periode 1968-1988 ketika Soeharto banyak mendapat kritikan dari para Jendral Angkatan Darat (Rizkindi, 2016: 20).
Ali Moertopo juga berperan Merumuskan tafsir hukum yang menjadi landasan bagi dwifugnsi ABRI. Menurutnya dwifungsi ABRI memiliki landasan konstusional dan landasan hukum sesuai dengan Pancasila dan UUD 1945. Salah satu dasar yang digunakan adalah Pasal 30 Ayat 1dan Pasal 10 UUD 1945. Dalam penjelasan Pasal 10 berbunyi, "kekuasaan-kekuasaan presiden dalam dalam pasal-pasal ini (antara lain pasal 10) ialah konsekuensi dari kedudukan presiden sebagai kepala negara". Dihubungkan dengan penjelasan UUD 1945 tentang kedudukan presiden berbunyi, "Di bawah MPR presiden ialah penyelenggara pemerintah negara yang tertinggi. Dalam menjalankan pemerintah Negara, kekuasaan dan tanggung jawab adalah di tangan presiden". Oleh karena itu Ali Moertopo menyimpulkan presiden dapat dan boleh menggunakan ABRI untuk mengembangkan Negara Pancasila segala bidang (Rizkiandi, 2016: 23).

Konsep dwifungsi $A B R I$ pertama kali dicetuskan oleh Jenderal A.H. Nasution pada November 1958. Berpidato di Akademi Militer Nasional (AMN) di Magelang, Nasution mengangkat pidato "Jalan Tengah". Isi pemikirannya merupakan hasil permenungan dan kekecewaan terhadap kemerosotan partai 
politik di mata Angkatan Darat, setidaknya dimulai sejak 1956. Kala itu Indonesia sedang berada di era Demokrasi Parlementer sehingga banyak partai politik bermunculan dan hanya terus melakukan kebisingan politik. Menurut Nasution mengatakan "bukan sekedar alat sipil seperti di negara-negara Barat, bukan sebuah rezim militer yang mendominasi kekuasaan negara, melainkan merupakan salah satu dari banyak kekuatan masyarakat, kekuatan demi perjuangan rakyat yang bekerja bahu-membahu dengan kekuatan lain yang dimiliki rakyat". Maksudnya militer harus terlibat dalam soal yang menyangkut keamanaan dan bidang-bidang lain. Namun keikutsertaan ABRI dalam pembinaan Negara bukan untuk memonopoli dan mendominasi kekuasaan (Rizkiandi, 2016: 23-24).

Sejumlah kesimpulan yang dicapai dalam seminar itu disebarluaskan kepada seluruh jajaran TNI (ABRI), juga dalam seminar tentang pertahanan dan keamanan pada November yang dihadiri seluruh pejabat tinggi empat angkatan, yaitu Angkatan Darat, Angkatan Laut, Angkatan Udara (AU) dan Angkatan Kepolisian (AK). Pertemuan ini menghasilkan "Doktrin Pertahanan Keamanan Nasional dan Doktrin Perjuangan Angkatan Darat Republik
Indonesia," dengan sub judul Catur Dharma Eka Karma ( Empat Tugas Satu Tujuan ). Di dalamnya ditekankan bahwa empat angkatan tersebut disatukan oleh satu doktrin. Menurut Maynard dokumen setebal 121 halaman ini menekankan bobot perluasan serta mempertegas konsep dwifungsi (Jenkins, 2010: 5).

Tentara dan polisi merupakan alat institusional yang bersifat koersif. Sementara lembaga-lembaga lainnya seperti pers, sistem pendidikan dan agama lebih memproyeksikan diri pada propaganda. Beberapa lembaga mengadopsi bentuk pseudo-demokratis, misalnya partai politik, MPR/DPR dan serikat pekerja untuk menunjukan 'kesetaraan' atau adanya 'persamaan hak'. Sistem hukum menggabungkan ketiga fungsi kelembagaan yakni meneror korbannya dipakai sebagai alat propaganda dan menjadi jubah legitimasi bagi kekuasaan (southwood \& Flanagan, 2012: 105).

ABRI menjadi berkepentingan mempertahankan keadaan yang demikian itu, mempertahankan rezim Orde Baru atau Rezim Soeharto. Dengan kata lain, ABRI dan Golkar berkepentingan mempertahankan status quo dan dengan demikian ia mereduksikan dirinya alat 
pelaksana belaka dari presiden atau Panglima Tertinggi Soeharto. Doktrin

Perjuangan TNI-ABRI "Catur Dharma Eka Karma" (CADEK) tahun 1988 yang menyebutkan bahwa "sebagai kekuatan sosial politik $A B R I$ merupakan teman seperjuangan yang sejajar dan sederajat dengan kekuatan sosial lainnya yang berpedoman Pancasila sebagai satusatunya asas" (pasal 38 ayat a ) (Soemardjan, 1999: 32).

Strategi pemerinah dalam menyelsaikan masalah ekonomi adalah dengan cara merekayasa kebijakan dan mendapatkan pinjaman dari luar negeri. Rapat dewan stabilitasi memutuskan melakukan diplomasi utang yang telah dirintis Sri Sultan Hamengkubuwono IX dan Adam Malik. Kedua tokoh ini melakukan safari ekonomi ke Negaranegara Barat dan Jepang untuk memperomosikan Orde Baru dan Strategi ekonominya. Hasilnya, Indonesia memperoleh kredit baru sebesar 120 juta dollar AS untuk impor kebutuhan pokok dan suku cadang dalam operasi penyelamatan. Selain itu, bantuanbantuan yang dibekukan kembali berlaku dan dialihkan dari tujuan konsumtifke suku cadang atau produktif senilai 167 juta dollar AS (Rizkiandi, 2016: 16).

\section{B. Konsep Nilai Dan Ajaran Jawa Bagi Kepemimpinan}

Sebenarnya dalam konteks kepemimpinan yang luas (dalam ajaran Jawa) terdapat pandangan mengenai bagaimana sosok pemimpin ideal itu. Sebagai satu etnik yang sangat mengedepankan kearifan lokal, masayarakat berpandangan bahwa raja atau pemimpin adalah "wakil atau titisan" Dewa atau Tuhan di muka bumi. Tugas mulia seorang pemimpin ini adalah menciptakan kehidupan yang harmonis antara manusia, alam, dan Tuhan. Di mana salah satu pilar utama hidup harmonis adalah keadilan. Oleh Karena itu, pemimpin yang adalah dia yang mampu menerjemahkan nilai- nilai keadilan dalam praksis kehidupan. Orangoran yang dipimpin harus mendapatkan rasa adil dan kesejahteraan lahir dan batin (Suyami: 99-100).

Dalam sastra cetha, Rama mengajarkan kepada Bharata bahwa apabila menjadi raja haruslah memperhatikan pedoman yang dinamakan sastra cetha. Sastra cetha sudah menjadi pegangan bagi para raja utama pada masa terdahulu dalam memegang tampuk pemerintahan. Inti ajaran sastra cetha adalah bahwa seorang raja harus bisa 
memahami tiga tingkatan nilai perbuatan, yaitu nistha (hina), madya (sedang), dan utama (terbaik). Perbuatan yang nistha harus benar-benar dihindari, jangan sampai menyentuh. Perbuatan madya cukuplah dimengerti, sadangkan perbuatan yang utama harus diusahakan untuk dilaksanakan (pupuh $\mathrm{V}$ bait 3 baris 6) (Suyami, 2008: 101-102).

Apabila dirumuskan secara lebih ringkas dalam perspektif kesejarahan satriya piningit (Ratu Adil) merupakan identifikasi terhadap sosok yang karismatik. la begitu diunggulkan karena ia adalah sosok kesatria utama yang secara sempurna memiliki lima belas sifat ksatria utama:

1. Wijaya (bijaksana dalam berbakti kepada Negara).

2. Mantriwara (senang hati berbakti kepada Negara).

3. Wicaksana maya (bijaksana dalam berbicara dan bertindak).

4. Matangwan (dikasihi dan dicintai rakyat).

5. Satya bakti prabu (setia kepada Negara dan tugas kepemimpinan).
6. Wakniwak (tidak berpura-pura, mulut dan hati bersatu).

7. Sarwan pasaman (sabar dan sareh,tidak gugup dalam hati).

8. Dirut saha (sungguh-sungguh dan setia).

9. Tan lelana (baik budi dan mengendalikan pancaindra).

10. Diwiyacita (menghilangkan kepentingan pribadi).

11. Masisi samasta buwana (memperjuangkan kesempurnan diri dan kesejahteraan dunia).

12. Sih samasta buwana (setia kepada Negara agar rakyat tertib dan makmur).

13. Dinrang pratidina (meninggalkan tindakan yang jelek dan mengutamakan tindakan yang baik).

14. Sumantri (menghamba seumur hidup).

15. Hanaya ken musuh (mengorbankan jiwa untuk Negara berlandaskan kebenaran dan keadilan) (Haq, 2011: 103-104).

Hal tersebut untuk memenuhi kewajiban raja, bahwa seorang raja harus 
memberi contoh yang baik bagi warganya.

Sebab apa pun yang diperbuat oleh raja, baik maupun buruk, pasti akan dicontohi oleh seluruh warga. Jika baik akan ditiru baik, begitu pula jika buruk pasti juga akan ditiru buruk (pupuh LXXVII bait 14 baris 6 7 , bait 15 baris 1 , bait 15 baris $5-7$, dan bait 16 baris 1-4) (Suyami, 2008: 115).

\section{Kultur Politik Tradisional Jawa Yang}

\section{Berimbas Pada Penyalahgunaan}

\section{Kekuasaan Era Orde Baru}

Munculnya kembali bentuk-bentuk pemerintahan sebelum masa kolonial Belanda sering mendapat komentar dan dikutuk oleh orang Indonesia. Bahkan tidak sedikit para petinggi militer terkemuka berharap Orde baru akan memenuhi janjinya pada 1966 untuk melakukan "koreksi total" setelah adanya beberapa ekses di masa lampau. Banyak kritikus mencela cara-cara Soeharto memerintah seperti "Mataram baru." Suatu sindiran dengan mengacu kerajaan penting di Jawa setelah 1582 dan pada keberhasilan presiden dalam membangun suasana kraton Jawa. Ini mengacu pada situasi di mana politik sering menjadi intrik dibalik layar dengan seorang "pangeran" yang kuat mempecundangi yang lain dengan adu domba guna menjunjung tinggi sang penguasa. Kritik lain menujuk pada praktik-praktik patrimonial yang merajalela di bidang ekonomi. Menurut para pengkritik ini, orang tidak perlu melihat jauh untuk menemukan penguasa yang mengikuti bentuk-bentuk tradisional dengan menggunakan kekuasaannya guna memberikan alokasi tertentu kepada para bawahanny (Jenkins, 2010: 20-21).

Salah satu kecendrungan yang kita amati dalam perpolitikan Indonesia adalah sebuah kecenderungan akan muncul budaya politik yang bersifat neopatrimonialistik. Harol Crouch (1979) telah mengungkapkan beberapa waktu yang lalu. Menurut hemat saya, apa yang dikemukan Crouch masih relevan untuk konteks kehidupan politik Indonesia saat ini. Dikatakan sebagai neo patrimonialistik, karena egara memiliki atribut yang bersifat modern dan rasonalistik seperti birokrasi, Tetapi juga memperlihatkan atribut yang sifatnya patrimonialistik (Gaffar, 1999: 115).

Konsep patrimonialisme yang dikembangkan oleh Max Weber (1968), cukup relevan kalau dikaitkan dengan pemerintah Orde Baru. Weber mengatakan bahwa sebuah negara disebut sebagai negara yang patrimonialistik, manakala "practically everything depends explicitly upon 
personal considerations: upon the attitude toward the concrete applicant and his concrete request, and upon purely personal connections, favors, promises, and privileges". Dalam negara yang patrimonialistik, penyelenggaraan pemerintah dan kekuatan militer berada di bawah kontrol langsung pimpinan negara, yang mempersepsikan segala sesuatunya mempribadi. Pada masa lampau, di Eropa, dukungan terhadap penguasa yang patrimonialistik diperoleh bukan dari kalangan aristokrasi, tetapi berasal dari kalangan budak dan tentara bayaran, yang secara langsung dikuasai sepenuhnya oleh penguasa. Hal itu dapat terjadi karena tidak adanya sistem ekonomi kapitalistik, kata Max Weber (Gaffar, 1999: 115).

Mengacu pada hubungan tradisional antara penguasa dan struktur pemerintahan yang diperintah, Anderson mencatat gambaran yang diberikan oleh Schrieke tentang struktur kerajaan Jawa sebelum masa kolonial Belanda. Dan secara menakjubkan begitu cocok dengan model Weber tentang negara patrimonial. Menurut ini pemerintah pusat pada dasarnya merupakan perluasan rumah tangga penguasa beserta pembantunya. Para pejabat diberi kedudukan dan hakhak penghasilan yang menyertainya sebagai penghargaan pribadi penguasa dan dapat diberhentikan atau diturunkan posisinya berdasarkan kemauan pribadi penguasa. Andeson mencatat, "Meskipun secara formal setruktur administrasi bersifat hirarkis, pada kenyataan terdiri dari sekelompok lapisan dalam hubungan patron dan klien." Selanjutnya, "Baik di daerah maupun di pusat pejabat dikelilingi oleh sekelompok bawahan pembantu pribadi dalam model penguasa teringgi." Nasib para bawahan tersebut tergantung pada kebehasilan atau kegagalan patron mereka (Jenkins, 2010: 19).

Dinyatakan pula oleh Max Weber, bahwa negara patrimonialistik juga memiliki sejumlah karakteristik yang mencolok. (1) kecenderungan untuk mempertukan sumber daya yang dimiliki seorang penguasa kepada temantemannya. (2) keijaksanaan seringkali lebih bersifat partikularistik daripada bersifat universalistik. (3) rule of law merupakan sesuatu yang sifatnya sekunder bila dibandinkan dengan kekuasaan dari seorang penguasa (rule of mam). (4) kalangan penguasa politik seringkali mengaburkan antara mana yang menyangkut kepentingan umum dan mana yang menyangkut kepentingan public. Lebih lanjut, Weber mengatakan bahwa dalam negara patrimonialistik sangat sulit diperkirakan rencana dan kebijaksanaan 
yang akan dipilih. Tentu saja hal itu bertentangan dengan konsep negara modern yang bersifat rasioalistik, sehingga segala sesuatunya dapat diprediksi. Selain itu kepentingan dari segelintir orang yang memiliki akses terhadap negara, yang tentu saja muncul karena pertimbangan yang sifatnya sangat khusus, sangat mewarnai kebijaksanaan negara (Gaffar, 1999: 115-116).

Istilah "pretorian" sebagai suatu bangsa menurut Nodlinger, di mana opsir militer menjadi "aktor politik utama yang lebih berkuasa disebabkan oleh kekuatan nyata atau ancaman kekerasan. Istilah pretorianisme diambil diambil dari Garda Pretoria kerajaan Romawi yang dibangun untuk melindungi kaisar, tetapi kemudian digunakan untuk menumbangkan para kaisar dan mengendalikan proses penujukan penggantinya. Sebagaimana ditulis Nordlinger, pretorianisme atau intervensi militer, timbul dalam berbagai situasi kudeta, terutama ketika para opsir itu sendiri mengambil kendali pemerintah. Dalam kasus-kasus semacam itu rezim sipil diubah menjadi rezim militer, meskipun sejumlah tokoh dan kelompok sipil tertentu sering mendapatkan kedudukan bagus akibat pengaruh politik (Jenkins, 2010: 22-23).

\section{KESIMPULAN}

Konsep dwifungsi $A B R I$ pertama kali dicetuskan oleh Jenderal A.H. Nasution pada November 1958. Berpidato di Akademi Militer Nasional (AMN) di Magelang, Nasution mengangkat pidato "Jalan Tengah". Isi pemikirannya merupakan hasil pemenungan dan kekecewaan terhadap kemerosotan partai politik di mata Angkatan Darat, setidaknya dimulai sejak 1956.

Kepemimpinan yang luas (dalam ajaran Jawa) terdapat pandangan mengenai bagaimana sosok pemimpin ideal itu. Sebagai satu etnik yang sangat mengedepankan kearifan lokal, masayarakat berpandangan bahwa raja atau pemimpin adalah "wakil atau titisan" Dewa atau Tuhan di muka bumi. Inti ajaran sastra cetha adalah bahwa seorang raja harus bisa memahami tiga tingkatan nilai perbuatan, yaitu nistha (hina), madya (sedang), dan utama (terbaik). Perbuatan yang nistha harus benar-benar dihindari, jangan sampai menyentuh.

Kebijakan Orde Baru, pengamat berkomentar atas kenyataan bahwa sistem pemerintahan Soeharto di Indonesia tampak sangat dipengaruhi oleh kultur politik tradisional Jawa. Mereka mengeluhkan sikap Soeharto yang telah menciptakan Kembali atmosfir keraton 
Jawa, di mana politik seringkali menjadi persoalan intrik kerajaan, di mana di dalamnya seorang 'pangeran' yang berkuasa diadu domba terhadap yang lain untuk keuntungan pemegang tampuk kekuasaan.

Neopatrimonialisme menyediakan segala rasionalisasi yang gampang serta "penjelasan" atas hampir segala ekses yang dapat dibayangkan dari sifat sentrisme dan oriterisme.

\section{DAFTAR RUJUKAN}

Andrain, Charles F. 1992. Kehidupan Politik dan Perubahan Sosial. Yogyakarta: Tiara Wacana Yogya.

AR. Hanta Yuda. 2010. Presidensialisme Setengah Hati: Dari di Lema ke Kompromi. Pt Gramedia Pustaka: Anggota IKAPI.

Budiardjo, Miriam. 1998. Partisipasi Dan Partai Politik: Sebuah Bunga Rampai. Jakarta: Yayasan Obor Indoesia.

Duverger, Maurice. 2005. Sosiologi Politik. Jakarta: PT RajaGrafindo Persada.

Gaffar, Afan. 1999. Politik Indonesia: Transisi Menuju Demokrasi. Yogyakarta: Pustaka Pelajar.

Haq, Muhammad Zaairul. Mutiara Hidup Manusia Jawa: Menggali Butir-Butir Ajaran Lokal Jawa untuk Menuju Kearifan Hidup Dunia dan Akhirat. Yogyakarta: Anggota IKAPI.

Handayani, Christina S. 2004. Kuasa Wanita Jawa. Yogyakarta: LKIS

Jenkins, David. 2010. Soeharto dan Barisan Jenderal Orba: Rezim Militer Indonesia 1973-1983. Jakarta: Komunitas Bambu.

Southwood, Julie \& Flanagan, Patrick. 2012. Terror Orde Baru:
Penyelewengan Hukum \&

Propogandanda 1965-

1981.Jakarta: Komunitas Bambu.

Soemardjan, Selo. 1999. Kisah Perjuangan Reformasi. Jakarta:

Pustaka Sinar Harapan. 